\title{
Macroamylasaemia in association with the acquired immunodeficiency syndrome
}

\author{
Ronald E. Greenberg, Simmy Bank and Carol Singer
}

Divisions of Gastroenterology and Infectious Diseases, Department of Medicine, Long Island Jewish Medical Center, New Hyde Park, NY 11042, USA.

\begin{abstract}
Summary: A patient with macroamylasaemia in association with the acquired immunodeficiency syndrome is described. Patients with the acquired immunodeficiency syndrome commonly have gastrointestinal symptoms that often prompt serum amylase determination. Macroamylasaemia has been found to occur in a variety of diseases including various autoimmune disorders. The marked immunological abnormalities and increased circulating immunoglobulins associated with the acquired immunodeficiency syndrome may have predisposed this patient to macroamylase formation. Macroamylasaemia is a benign condition that requires no treatment and must be excluded in the patient with unexplained hyperamylasaemia to avoid unecessary diagnostic tests and treatment.
\end{abstract}

\section{Introduction}

Infection with human immunodeficiency virus (HIV) results in profound dysfunction of both cell-mediated and humoral immunity predisposing patients to severe opportunistic infection and Kaposi's sarcoma. Patients with the acquired immunodeficiency syndrome often develop multi-system organ damage including widespread involvement of the gastro-intes- tinal tract. The development of abdominal symptoms often prompts serum amylase determination.

Patients with unexplained hyperamylasaemia are often subjected to multiple diagnostic tests or even laparotomy. Macroamylasaemia is a frequently overlooked cause of hyperamylasaemia and must be excluded to avoid making erroneous diagnoses. We report the first case of macroamylasaemia in association with the acquired immunodeficiency syndrome.

\section{Case report}

A 23 year old promiscuous heterosexual male was hospitalised after two months of fever, dyspnoea, and chest pain. Seven months previously oral candidiasis was noted and four months before admission a routine blood count revealed a leucocyte count of $1.9 \times 10^{9} / 1$ and platelet count of $1.17 \times 10^{9} / 1$. For two months before admission he experienced fever, chills, night sweats, non-productive cough and dyspnoea on exer-

Correspondence: Ronald E. Greenberg, M.D., Division of Gastroenterology.

Accepted: 18 February 1987 tion. Physical examination was remarkable for mucocutaneous candidiasis, small non-tender bilateral cervical and axillary lymph nodes and a palpable spleen tip. Serum immunoglobulin determination by radial immunodiffusion revealed an IgM of $840 \mathrm{mg} / \mathrm{dl}$ (normal $56-352$ ) an IgA of $900 \mathrm{mg} / \mathrm{dl}$ (normal 70-312), and an IgG of $2100 \mathrm{mg} / \mathrm{dl}$ (normal 639-1349). The T4/T8 lymphocyte ratio was 0.17 (normal 1.2-3.8), and HIV antibody was detected by Western blot testing. Flexible fibreoptic bronchoscopy with trans bronchial biopsy and bronchoalveolar lavage revealed abundant Pneumocystis carinii on Gomori's methenamine silver stain. Therapy was instituted with pentamidine isethionate $250 \mathrm{mg}$ administered intravenously over one hour daily.

On the tenth hospital day he experienced multiple episodes of bilious vomiting, but denied any abdominal pain or distension. Serum amylase was 3480 IU (normal 60-160); creatinine was $159 \mathrm{mmol} / 1$, SGOT-68 U/1 and SGPT, alkaline phosphatase and bifirubin were normal. Repeat serum amylases were 2990 IU and 3180 IU with quantitative urine amylases of 21 units/hour and 9 units/hour (normal 50-400 U/ h). The vomiting and mild renal insufficiency were attributed to pentamidine and subsided 48 hours after therapy was changed to trimethoprim sulphamethoxazole. Computerized tomographic examination of the pancreas was normal. Polyethyleneglycol 6000 precipitated $82 \%$ of the patient's serum amylase consistent with macroamylasaemia. In addition, determination of amylase isoenzymes by cellulose acetate electrophoresis revealed a diffuse and wide- 
spread band midway between the pancreatic and salivary peaks confirming macroamylasaemia. Six months after resolution of the Pneumocystis carinii pneumonia serum amylases continue to remain at approximately $3000 \mathrm{IU} / 1$.

\section{Discussion}

Macroamylasaemia occurs when normal circulating serum amylase binds to another serum protein forming a high molecular weight complex that is too large to be excreted in the urine. The macroamylase is usually a complex of $S$ type amylase bound to an immunoglobulin or occasionally a polysaccharide. ${ }^{1}$ It occurs in $1.0 \%$ of the general population, $2.5 \%$ of patients with hyperamylasemia, and $29 \%$ of patients with chronic unexplained hyperamylasaemia. ${ }^{2,3}$ It is an acquired condition of uncertain significance that may represent a nonspecific dysproteinaemic response to disease. $^{1}$

Macroamylasaemia has been found to occur in association with a variety of diseases including diabetes mellitus, cancer, alcoholism, systemic lupus erythematosus, and liver disease and occurs with greater frequency in patients with disturbed humoral immunity and autoimmune diseases. In the latter setting, macroamylasaemia may reflect an aberrant state of immunoglobulin production. ${ }^{1}$ It has also been described in malabsorption syndromes and other inflammatory diseases of the gut suggesting increased absorption of luminal antigen from altered gut permeability. ${ }^{4}$ The significance of macroamylasaemia in apparently healthy persons is unknown and it remains unclear whether this represents an early marker of disease. However, the correlation in some patients between macroamylase level and fluctuations in activity of underlying disease suggests a direct relationship between the two conditions. ${ }^{5}$

The acquired immunodeficiency syndrome (AIDS) is characterized by a profound alteration in both the

\section{References}

1. Klonoff, D.C. Macroamylasemia and other immunoglobulin-complexed enzyme disorders. West J Med 1980 , 133: 397-407.

2. Kleinman, D.S. \& O'Brien, J.F. Macroamylase. Mayo Clin Proc 1986, 61: 669-670.

3. Levitt, M.D., Ellis, C.J. \& Meier, P.B. Extrapancreatic origin of chronic unexplained hyperamylasemia. $N$ Engl J Med 1980, 302: 670-671.

4. Hodgson, H.J.F., Whitaker, K.B. \& Cooper, B.T. Malabsorption and macroamylasemia - response to gluten withdrawal. Am J Med 1980, 69: 451-457. cellular and humoral arms of the immune system. ${ }^{6} \mathrm{The}$ polyclonal B cell activation, increased spontaneou immunoglobulin secretion, and elevated levels ơ serum immunoglobulins and circulating immune com= plexes in AIDS may predispose these patients t $\overrightarrow{\mathrm{d}}$ macroamylase formation. In addition, the enteropathy of AIDS may result in the presentation of an increased antigenic load through the disease mucosa to the enteric immune system similar to that described in patients with other malabsorption syre dromes and macroamylasaemia. ${ }^{7}$

This patient has type I macroamylasaemia charac terized by an increased serum amylase and a low urinary amylase. An abnormally low ratio of amylase to creatinine clearance is a useful screening test fo: type I macroamylasaemia. However, a low ratio is no甲 specific for macroamylasaemia and would not exclude. type II macroamylasaemia which is associated wit 8 hyperamylasaemia and a normal $\mathrm{C}_{\mathrm{am}}: \mathrm{C}_{\mathrm{cr}}$ ratio or type III which is associated with normal levels of serum and urine amylase. If available, a serum lipase assay is useful to exclude pancreatic disease as a cause of hyperamylasaemia. The selective precipitation of at least $73 \%$ of macroamylase by polyethylene glycot (PEG) 6000 provides a simple assay to detect it presence. ${ }^{8}$ PEG 6000 precipitated $82 \%$ of this patient amylase and cellulose acetate electrophoresis reveale ${ }^{f}+$ the typical broad band intermediate between salivor $\vec{b}$ and pancreatic isoamylase peaks confirming macroamylasaemia. ${ }^{9}$ Although we cannot exclude existing macroamylasaemia we believe the marke immunological abnormalities as reflected by a reduce T4/T8 lymphocyte ratio and increased circulating immunoglobulins may have predisposed this patien to macroamylase formation.

Macroamylasaemia is a benign condition tha $\overrightarrow{\vec{\Phi}}$ requires no special treatment. Gastrointestinal symp toms commonly occur in AIDS and often promp serum amylase determination. Macroamylasaemia. should be excluded in patients with AIDS and hyperamylasaemia to avoid an invasive and prolonge workup.

5. Zimmerman, H.M., Bank, S., Buch, P., Katzka, I. Lendvai, S. Macroamylase in the pleural fluid of patient with lymphoma. Gastroenterology 1983, 55: 190 193.

6. Lane, H.C., Masur, H., Edgar, L.C. et al. Abnormalitie of B-cell activation and immunoregulation in patients with the acquired immunodeficiency syndrome. $N$ Engl Med 1983, 309: 453-458.

7. Kotler, D.P., Goetz, H.P., Lange, M. et al. Enteropathy associated with the acquired immunodeficiency syndrome. Ann Intern Med 1984, 101: 421-428. 
8. Levitt, M.D. \& Ellis, C. A rapid and simple assay to determine if macroamylase is the cause of hyperamylasemia. Gastroenterology 1982, 83: 378-382.
9. Legaz, M.E. \& Kenny, M.A. Electrophoretic amylase fractionation as an aid in diagnosis of pancreatic disease. Clin Chem 1976, 22: 157-162. 